\title{
THE EFFECT OF NON-RECURRING ITEM TRANSACTIONS ON THE POSSIBILITY OF FIRMS TO SMOOTH INCOME: THE CASE OF INDONESIAN LISTED FIRMS
}

\author{
Theresia Trisanti \\ Sekolah Tinggi Ilmu Ekonomi YKPN, Yogyakarta \\ e-mail: thtrisanti@yahoo.com \\ thtrisanti@gmail.com
}

\begin{abstract}
This research examines one of the prevalent examples of creative accounting, which is the income smoothing. Income smoothing is defined as a deliberate dampening of fluctuations about some level of earnings considered to be normal for the firm (Chong, 2008).In this study, incomesmoothing practices of Indonesian listed companies are detected through empirical tests using non-recurring item transactions as income smoothing instrument. Income smoothing is accepted as motivation of non-recurring item transactions. The data used are the financial reports of each sample company, which obtained through DataStream from 2009- 2013. Sample firms are classified as smoothers and non-smoothers using modified Moses smoothing behavior index (Atik, 2009). Results show that possible motivation of non-recurring items transactions are income smoothing practices. Logistic regression result show that independent variables such as profitability, debt financing have significant influence to income smoothing practices but company size have no significant influences.
\end{abstract}

Keywords: income smoothing practices, non-recurring item transactions, company size, debt financing and profitability.

\begin{abstract}
Abstrak
Riset ini meneliti salah satu kreativitas akuntansi yaitu pemerataan laba. Pemerataan laba didefinisikan sebagaitindakan manajemendengan sengaja meratakanfluktuasi laba perusahaan ketingkat laba yang dianggap normal untuk perusahaan sejenis (Chong 2008). Dalam riset ini, praktek pemerataan laba perusahaan Indonesia yang terdaftar di Bursa Efek Indonesia dideteksi melalui bukti empirik dari transaksi item-tem yang jarang terjadi yang digunakan sebagai instrumen untuk pemerataan laba. Data yang digunakan untuk penelitianadalah laporan keuangan dari perusahaan yang diperoleh melalui DataStream periode 2009- 2013. Sampel perusahaan diklasifikasikan sebagai yang perusahaa yang melakukan pemerataan laba dan tidak melalukan pemerataan laba denganmenggunakan Moses Indexyang sudah dimodifikasi (Atik 2009). Hasil penelitian menunjukkan bahwa melalui transaksi item- item yang tidak biasa, perusahaan dapat melakukan transaksi pemerataan laba.Hasil uji regresi menunjukkan bahwa variabel independen seperti profitabilitas dan jumlah utang berpengaruh terhadap praktik pemerataan laba tetapi ukuran perusahaan tidak berpengaruh terhadap praktik pemerataan laba.
\end{abstract}

Kata kunci: praktik pemerataan laba, transaksi item-tem yang jarang terjadi, ukuran perusahaan, jumlah utang dan profitabilitas.

\section{INTRODUCTION}

Recently, public has witnessed a number of well-known financial accounting scandals involving large companies in developed countries such as Enron (2001), Parmalat (2003)
Bernard L. Madoff Investment Securities (2008) and Bear Stearns (2008). Beside scandals in developed countries which have sophisticated capital markets and regulations, similar cases were also happened in developing countries with emerging capital markets. 
For example, Indonesia has also experienced the similar cases, PT Bumi Resources (2008), PT Semen Cibinong (2008) and PT Bank Century (2009). The weaknesses or lapses in accounting practices of these companies have been identified as one of the some financial issues which led to those scandals. Basically generally accepted accounting principles (GAAP) offer some flexibility in preparing the financial statements and give the financial managers some freedom to select among accounting policies and alternatives (Chong 2008). Some accounting manipulation practices used the flexibility in financial reporting to alter the financial results of the firm. For example, management can misrepresent the timing, amount, or intent of transactions and events related to revenues or expenses without being involved in fraud or falsification of the records (Rezvan et al. 2011). Management can also take advantage of generally accepted accounting principles (GAAP) to select from various methods when computing earnings and other financial measures which could lead to lower quality financial information. This discretionary room allows management to report the desired profit, achieving its goals at the interest of other parties. As a result, phrases such as earnings management, creative accounting, income smoothing, and the big bath accounting have emerged.

One form of creative accounting is the income smoothing (IS) practice in which company's management takes steps to reduce and store earnings during the good years and defer them for use during the businessdownturn years or vice versa or in other words income smoothing is deliberate dampening of fluctuations about some level of earnings considered to be normal for the firm (Atik 2009; Stolovy and Bartov 2004; Charfeddine and Bouaine 2012.). Therefore smoothing of reported income may be defined as the intentional dampening or fluctuations about some level of income that is currently considered to be normal for a firm. In this sense smoothing represents an attempt on the part of firm's management to reduce abnormal variations in income.Previous studies show that income smoothing practices are fairly common phenomenon. It has been detected in varying degrees across different samples. Atik (2009) has referred to income smoothing practice as one of the common abuses in financial reporting that users should be wary of and he has described it as a manipulation of financial information. Hence, the concern about income smoothing practices need for appropriate research. This paper examines one of the prevalent income smoothing instruments, which is the non-recurring items transaction. Heflin et al. (2002) indicate the nonrecurring items such as the frequency of material write-downs and write-offs have been increasing rapidly since in 1995.

Given the above explanation, there are two objectives of this paper are as follows: 1) To verify the effect of non-recurring items to the income smoothing practice among Indonesian public listed company. 2) To identify company specific factors, such as: firm size, profitability and debt financing to the incidence of income smoothing practices by Indonesia listed companies.

\section{LITERATURE REVIEW}

Albrecht and Richardson (1990) introduced the concept of income smoothing when he proposed that it was logical and rational for managers to attempt to smooth income by using certain accounting devices. He suggested several reasons for income smoothing. First, through the judicious 'juggling' of income and expense items over a period of years, management can reduce a company's overall tax liability. Second, a smooth income stream can enhance investor confidence because stable earnings support a stable dividend policy, which is desirable. Third, income smoothing can enhance the relations between managers and workers because a sharp increase in reported profits may lead to demands for higher wages. Fourth, smooth income streams can have a psychological impact on the economy in those cyclical upswings and downswings can be countered and waves of optimism and pessm ism moderated. 


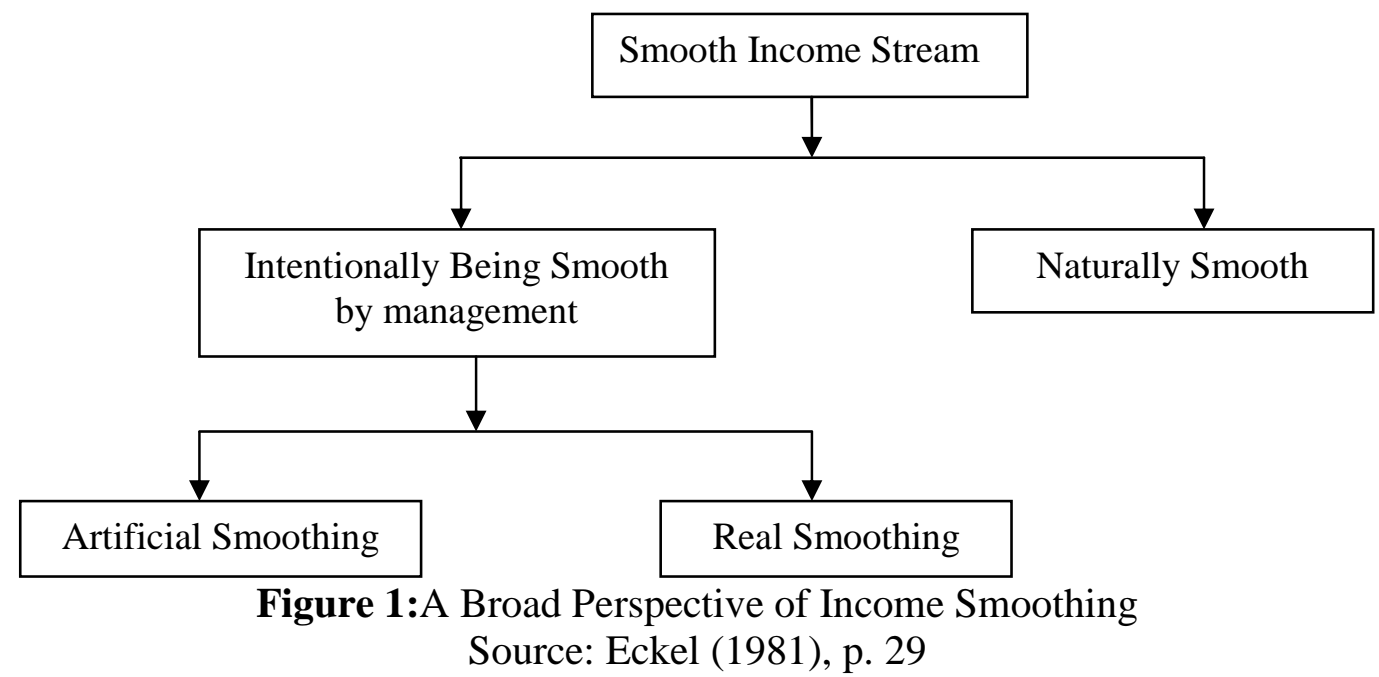

Furthermore, there are two different types of smoothed income streams: those that are naturally smoothed and those that are intentionally smoothed by management (Eckel 1981). From this diagram, intentionally smoothed income is further classified into two types of smoothing, artificial smoothing and real smoothing. All these types of smoothing could be generally described as follow; a naturally smoothed income stream occurs when a firm's income generating process inherently produces a smoothed stream of reported income. For example, one would expect the income generating process of public utilities to be such that income streams would be naturally smoothed (Atik 2009; Rezvan et al. 2011).

An intentionally smoothed income stream can be the result of real smoothing or artificial smoothing. Real smoothing involves decisions that affect cash flows and dissipate firm value. Examples include changing the timing of investments and providing promotional discounts or vendor financing to risky customers to pump up sales toward the end of the quarter (Atik 2009). Meanwhile, artificial smoothing represents accounting manipulations taken by management using flexibility in the accounting standards to alter the reported number. These manipulations do not represent underlying economic events or affect cash flows, but shift costs and/or revenues from one period to another (Mohammad and Ehsan 2011). For example, a firm could increase or decrease reported income simply by changing its actuarial assumptions concerning pension costs. Previous studies have investigated IS instrument such as dividend income, pension costs, investment tax credit, depreciation and fixed charges, accounting policies changes and reserves and provisions. Research publications provide examples of a broader IS strategy that involves another instrument: timing for nonrecurring items transactions as a smoothing instrument. Some researches indicate the nonrecurring items such as the frequency of material write-downs and write-offs have been increasing rapidly since in 1995 (Gu and Chen 2004; Stefanescu 2009). A broad perspective of income smoothing behavior is diagrammatically presented in Figure 1.

According to Indonesian Generally Adopted Principles (PSAK) number 25, paragraph 15 , non-recurring items is an abnormal or infrequent gains or losses are reported in the company's annual report. They are rare events or activities that are not part of the company's normal business operations. Examples of nonrecurring items include losses due to fire or theft, the write-off of a company division, the acquisition of another company, or the one-time sale of a large piece of property, and discontinued operations. All those items are typically non-recurring items in the company's income statements. The increasing non-recurring item transactions make the importance of the treatment accorded nonrecurring adjustments to income. In the majority of cases, current practice requires that non- 
recurring adjustments be classified in the operating se tion of the income statement at their pre-tax value. In particular, it is hypothesized that the current practice of classifying items of non-recurring nature into the operating section of the income statement decreases the predictive ability of income before extraordinary items. Since most adjustments are of a nonrecurring nature, it can be hypothesized that they distort income and income per share figures for users of financial statements whose principal interest is in their predictive ability (Abdullah et al. 2002). Research by Black et al. (2000) explained that nonrecurring items occur with at least two possible explanations: (1) Multiple occurrences of nonrecurring items indicate that companies are in financial difficulty, or they indicate companies whose managers have engaged repeated attempts at earning management or IS. (2) They also find that companies with multiple occurrences of nonrecurring items are four times more likely to eventually file for bankruptcy or liquidation than other companies.

Accordingly nonrecurring items are the product of managers' exercise of choice and judgment in determining the timing of the transaction, the amount of its financial impact, and the period of reporting. There also is a managers' discretion in deciding when the gain or loss is to be reported, whether the gain or loss is to be recognized at the point of sale; or whether they are to be recognized upon the receipt of cash or a claim to cash; or whether they are to be recognized upon the completion of some other critical event.Thus, they can be conveniently classified as non- recurring items for the purposes of smoothing income (Mohammad and Ehsan 2011). According to Moses (1997) the smoothing instruments are the variables used by managers in attempting to smooth particular accounting figures. Therefore, an accounting practice or measurement rule must possess certain properties before it may be used as a manipulative smoothing instrument, for this research the observations on the notes of financial statements refer to the non-recurring item transactions. Abdullah et al. (2002) stated the identification of the na- ture of nonrecurring items reported by each company is a difficult exercise due to the fact that most companies reported more than one nature of nonrecurring items in a particular year. By going through the annual reports, the nature of the nonrecurring items will be subsequently classified into eight major categories, as shown in Table 1.

Table 1: Nature of Nonrecurring Items

\begin{tabular}{ll}
\hline No. & Description \\
\hline 1 & $\begin{array}{l}\text { Sales/disposal of long term investments } \\
\text { Sales/disposal of property, plant and } \\
\text { equipment }\end{array}$ \\
3 & $\begin{array}{l}\text { Goodwill written off } \\
4\end{array}$ \\
5 & $\begin{array}{l}\text { The write off assets to recoverable amount } \\
6\end{array}$ \\
$\begin{array}{l}\text { Extraordinary Income in associated compa- } \\
\text { nies }\end{array}$ \\
7 & $\begin{array}{l}\text { Expenses related to listing and issue of se- } \\
\text { curities }\end{array}$ \\
8 & $\begin{array}{l}\text { A restructuring of the activities of an enter- } \\
\text { prise and the reversal of any provision for } \\
\text { the costs of restructuring }\end{array}$ \\
\hline
\end{tabular}

Source: Adapted and revised from Abdullah et al. (2002) and PSAK 25 (paragraph17)

\section{HYPOTHESIS DEVELOPMENTS}

As explain in the review literature section, for this paper the non-recurring item was selected as a smoothing device for several reasons. Manipulation of nonrecurring item adjustments is one of the most readily discernible of a wide variety of stratagems and practices available for smoothing reported profit. Nonrecurring items are the product of managers' exercise of choice and judgment in determining the timing of the transaction, the amount of its financial impact, and the period of reporting. Company managements also have a considerable scope, for example, to smooth reported profit figures by nonrecurring item transactions such as sales/disposal of long term investments, sales/disposal of property, plant and equipment, the write off assets to recoverable amount (Cameron and Stephen 1991; Beattie et al. 1994). Accordingly the hypothesis for this paper is stated as follows:

$\mathrm{H}_{1}$ : There is a significant relationship between the non-recurring item transactions and 
the level of income smoothing practices by Indonesian listed firms.

Previous studies conclude that a high proportion of companies smooth their income when their profitability is relatively low. Atik (2009) provide evidence that companies with declining profitability tend to smooth their income. Presumably, fluctuations in income streams have a more severe impact on low profitability companies; hence, they have a stronger motivation to smooth income. Given these findings, it is hypothesized that companies with lower profitability tend to smooth their income more than companies with higher profitability. In this paper, profitability is measured by the ratio of profit before interest and tax to total assets minus current liabilities (Mansor and Achmad 2009). Accordingly, the hypothesis is formulated as follows:

$\mathrm{H}_{2}$ : There is a significant relationship between profitability and the level of income smoothing practices by Indonesian listed firms.

The debt equity hypothesis maintains that the higher the firms' debt, which is equivalent to the close (i.e. 'tighter') the firms is to the constraints in the debt covenants and the greater the probability of a covenant violation and of incurrence of technical default cost,the more likely managers are to use accounting methods that increase income. Ashari et al. (1994) and Atik (2009) suggest that the issuance of debts provides an incentive for a firm to smooth its reported income. They will do this to loosen the binds of any debt covenants that are expressed in terms of accounting-based numbers. The objective of this process is to minimize the costs associated with agency relationship and thus maximize the shareholders and the bondholders' wealth. Therefore, a positive association between income-smoothing behavior and total long-term debt to total assets ratio (TD/TA) is expected. Like the other hypotheses of this paper, this hypothesis implies the expected direction of the association between debt financing and IS practices; the relevant hypothesis is as follows:
$\mathrm{H}_{3}$ : There is a significant relationship between debt financing and the level of income smoothing practices by Indonesian listed firms.

Previous studies find that company size has an effect on income smoothing behavior. For examples Habib (2002) and conclude that small companies smooth income significantly more than large companies. One explanation is that smaller companies are likely to be subject to less public scrutiny than larger companies, therefore small companies are expected to smooth income more than large companies. In other words, larger companies are likely to receive more attention from analysts and investors and thus more is known about them. Consequently, there is little additional value for a smoothed income signal and, accordingly, larger companies have less incentive to smooth income (Mansor and Achmad 2009; Habib 2002). In this paper, the company size is measured by total assets (after taking logarithms). Thus, the hypothesis tested in the paper can be summarized as follows:

$\mathrm{H}_{4}$ : There is a significant relationship between company size and the level of income smoothing practices by Indonesian listed firms.

\section{RESEARCH METHODOLOGY}

According to Atik (2009) and Moses (1987) smoothing was measured as the degree to which an accounting change shifts income toward expected earnings (EE). For each sample firm the earnings number that would have been reported had the firm not doing nonrecurring item was determined and termed pre-change earnings (PE). A measure of smoothing behavior (SB) was calculated by comparing the deviations of pre change and reported earnings (RE) from expectations. Therefore PE, RE, and EE are all un-deflated measures and consequently dependent on firm sales was used here as a deflator (Atik 2009). Based on this model income smoothing is measured as the degree to which an accounting change shifts income toward expected earnings (EE). The calculation of pre-change 
earnings (PE) is the earnings number that would have been reported if the firm not doing non-recurring item transactions.

$$
S B=\frac{|P E-E E|-|R E-E E|}{S A L E S}
$$

Where:

$\mathrm{SB}=$ the smoothing behavior, positive values of SB mean the analyzed firm is an income smoother, negative values is nonsmoothing firms.

$\mathrm{PE}=$ the pre-change earnings, the earnings number that would have been reported had the firm not doing non-recurring item.

$\mathrm{EE}=$ the expected earnings, an accounting change shifts income toward expected earning.

$\mathrm{RE}=$ the reported earnings, calculated by comparing the deviations of pre change and reported earnings.

A measure of smoothing behavior is calculated by comparing the deviations of prechange and reported earnings from expectations. Since PE, RE, and EE are all undeflated measures and consequently dependent on sales are used here as a deflator. A simple random walk model (SRWM), predicting earnings in any year as equal to reported earnings in the previous year, is used for the tests in this paper. It is because the expected earnings depend solely on the most currently observed earnings. In this model, it is assumed that the management making non-recurring item transactions to keep the current year's earnings level at least equal to the last year.
Smoother and non-smoother firms are distinguished by the sign of the amount that is generated by the application of the above formula. Positive values of SB mean the analyzed firm is an income smoother (Atik 2009; Mohammad and Ehsan 2011). Diagrammatically the statistical model above can be described as in Figure 2 and 3.

The hypotheses $\left(\mathrm{H}_{2}\right.$ up to $\left.\mathrm{H}_{4}\right)$ are to investigate the association between company specific variables to IS practices. This association was modeled using the logistic regression. Using this model, the dependent variable only contains two categories: the income smoothing status of companies, which 1 is for smoothers and 0 for non-smoothers. The logistic regression determines the impact of multiple independent variables presented simultaneously to predict membership of one or other of the two dependent variable categories (smoothing and non-smoothing) and the independent variables are either interval or nominally measured (McClave et al. 2011; O'Connell 2005).

The logistic regression model can be expressed as follows:

$$
\begin{aligned}
\operatorname{Logit}(\text { pi })= & \ln [\mathrm{pi} / 1-\mathrm{pi}]=\alpha+\beta_{1} \text { PRTi } \\
& +\beta_{2} \text { DEBTi }+\beta_{3} \text { SIZEi }
\end{aligned}
$$

Where:

$\mathrm{i} \quad=1, \ldots, \mathrm{n}$,

pi $=$ the probabilities values of $i^{\text {th }}$ firm smooth its income

PRT = Profitability

DEBT $=$ Debt Financing

SIZE $=$ Size

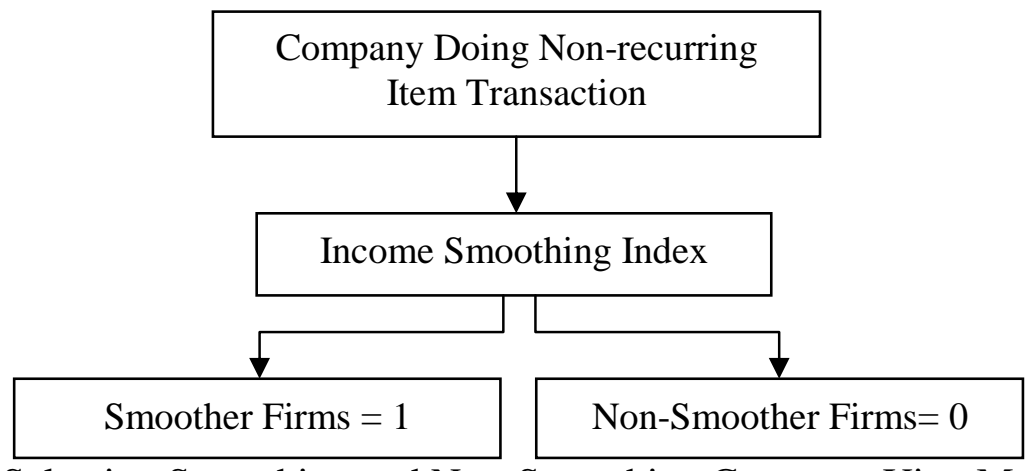

Figure 2: Selecting Smoothing and Non-Smoothing Company Uisng Moses Index 


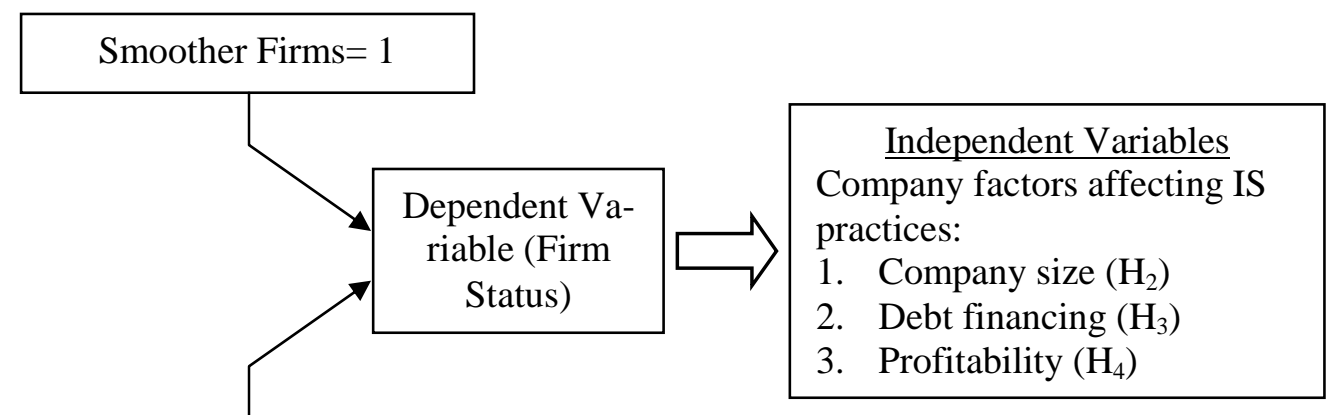

Non-Smoother Firms $=0$

Figure 3:Diagram of the Logistic Regression Test

\section{SAMPLE USED IN THE RESEARCH}

The population of interest selected for this paper comprised firms listed on the Indonesia Stock Exchange and the DataStream database were used for the period of 2009 up to 2013. The year 2009 is taken as the initial year as the paper has employed a five year time series data collections. Refer to Stolowy and Bartov (2004) the term smoothing implies adjustments to income smoothing in two or more consecutive periods and it required analysis of data for at least four periods. The results of some studies suggest that an increase in the time period tends to reduce errors of misclassification of firms as smoothers and nonsmoothers, therefore this study has employed a five year time series data collections.

\section{DATA ANALYSIS AND DISCUSSION}

The first research objective is to examine the effect of the IS instruments; non-recurring items to the IS practices. The final sample consisted of 156 firms for the period of 20092013. All the selected listed firms in this study had 5 years complete financial report and the independent variables data are available. Therefore, the data used for this study was panel data and were analyzed using quantitative method to facilitate statistical hypothesis testing.Table 2 shows the number of firms doing nonrecurring items to smooth their income. It also presents the number of firms categorized as smoother and non-smoother based on smoothing behavior index using the simple random walk model (SRWM) to estimate the expected earnings. The observation on the notes of the financial reports and auditor reports of the firms were made to find out the consistency of the selection of accounting methods. These observations were made on financial reports to determine the tendency of using non-recurring item transactions. After going through the annual audit reports, the nature of the non-recurring item transactions was subsequently classified into six major categories according to their types as shown in Table 2.

Table 2: Firms Doing Nonrecurring Item by Period

\begin{tabular}{llccccc}
\hline No. & \multicolumn{1}{c}{ Description } & 2009 & 2010 & 2011 & 2012 & 2013 \\
\hline 1 & Sales/disposal of long term investments & 10 & 8 & 11 & 7 & 6 \\
2 & Sales/disposal of property, plant and equipment & 13 & 14 & 12 & 13 & 10 \\
3 & Goodwill written off & 1 & - & - & - & - \\
4 & The write off assets to recoverable amount & 10 & 10 & 6 & 7 & 5 \\
5 & Discontinues operation & 8 & 7 & 8 & 2 & 4 \\
6 & $\begin{array}{l}\text { Expenses related to listing and issue of securi- } \\
\text { ties }\end{array}$ & 6 & 2 & 3 & 1 & 1 \\
\hline & Total firms doing non-recurring items & 48 & 41 & 40 & 30 & 26 \\
\hline
\end{tabular}


Table 3: Percentage (\%) of Smoother and Non-smoother Firms According to SRWM Model

\begin{tabular}{cccccc}
\hline Year & Total Firms Doing Non- & Categorized as Non- & \multicolumn{3}{c}{ Categorized as } \\
Securring Transactions & Smoother Firms & $\%$ & Smoother Firms & $\%$ \\
\hline 2009 & 48 & 16 & $33 \%$ & 32 & $67 \%$ \\
2010 & 41 & 14 & $34 \%$ & 27 & $66 \%$ \\
2011 & 40 & 16 & $39 \%$ & 24 & $61 \%$ \\
2012 & 30 & 14 & $47 \%$ & 16 & $53 \%$ \\
2013 & 26 & 17 & $65 \%$ & 9 & $35 \%$ \\
\hline
\end{tabular}

As seen in Table 2 for non-recurring transactions, managers mostly preferred to sold or disposal of property, plant and equipment and second to sell or disposal of long term investments. The third most prevalent nonrecurring item transactions type is discontinues operation. From the sample of firms doing nonrecurring item transactions selected in this stage, the researcher calculated an "expected" earnings number that the firms would use to smooth their income. Expected earnings are used as a reference point from which measures of the deviation of actual earnings can be developed. Positive values of smoothing behavior (SB) mean that the analyzed firm is an income smoother (Atik 2009). By using a smoothing behavior index, firms were categorized as smoothers and non-smoothers. Table 3 shows the number of smoother and non-smoother firms that were determined according to simple random walk model (SRWM) model.

As presented in the Table 3, in the first year (2009) there were $33(67 \%)$ of the sample firms had positive SB values and therefore were classified as income smoothers. In the second year (2010) there are 27 firms $(66 \%)$ of the sample firms had positive values of SB and they were classified as smoothers from the total of 41 firms. In the last years, on the last year in 2013 there were 9 firms $(35 \%)$ out of 26 firms had positive SB values. This findings concluded that the highest percentage of using non-recurring item transactions (67\%) in 2009 , and the lowest of non-recurring item transactions (35\%) in 2013 and also assert that Indonesian listed firms tend to use nonrecurring item transactions as income smoothing instrument to smooth their income figure.

The second research objectives are to investigate the association between company specific variables to IS practices. This association was modeled using the logistic regression. Using this model, the dependent variable only contains two categories: the income smoothing status of companies, which 1 is for smoothers and 0 for non-smoothers. The logistic regression determines the impact of multiple independent variables presented simultaneously to predict membership of one or other of the two dependent variable categories (smoothing and non-smoothing) (Elliot and Woodward 2007).

Appendix 1 shows the logistic regression output with the logistic regression model which is as follows:

$$
\begin{aligned}
\operatorname{Logit}(\mathrm{pi})= & \ln \left[\mathrm{p}_{\mathrm{i}} / 1-\mathrm{p}_{\mathrm{i}}\right]=\alpha+\beta_{1} \operatorname{SIZEi}+\beta_{2} \\
& \operatorname{DEBT}_{\mathrm{i}}+\beta_{3} \mathrm{PRT}_{\mathrm{i}}
\end{aligned}
$$

From these outputs, the estimated logistic regression equation in 2009 can be determined as follows:

$$
\begin{aligned}
\operatorname{Logit}(\mathrm{pi})= & 9.718-0.658 * \mathrm{SIZE} \\
& +1.191 * \text { DEBT }-2.429 * \mathrm{PRT}
\end{aligned}
$$

Similarly, the logistic regression for other period can be determined by replacing the $\beta_{\mathrm{i}}$ in the model with the related number in the column B of Appendix 1.The result of Appendix 1 shows the model Chi-square which tests the joint null hypotheses that all slope coefficients are zero proves to be statistically significant at the $1 \%$ level for all five periods. This implies that the three model's predictors are able to predict the IS practices. The Negelkerke $\mathrm{R}$-square was 0.753 in 2009, 0.802 in the 2010, and was 0.842 in 2013. It means that on the average the model's predictors could explain $77.4 \%$ in the variation of the smoothing practices. This percentage indicates a moderately strong relationship of $77.4 \%$ between the predictors and the prediction (O'Connell 2005).

To test the reliability of the estimated model, the study used the Hosmer and Lemeshow (H-L) goodness-of-fit test in testing the difference between the model's predicted val- 
ues and the observed values. If the H-L goodness-of-fit test is greater than 0.05 , as wanted for well-fitting model, then one fails to reject the null hypothesis that there is no difference between the observed and model-predicted value (O'Connell 2005). This implies that the model's estimates fit the data at an acceptable level. This means that well-fitting models show non-significance on the H-L goodness of fit test. This desirable outcome of nonsignificance indicates that the model prediction does not significantly differ from the observed.With these in mind, the p-value of 0.430 in the 2013, which is computed from the Chisquare distribution with 8 degrees of freedom, is not statistically significant and, therefore, the used model was quite a good fit. The same findings occurred for the period after the introduction of CG Codes and for the period after the convergence to IFRS, which means that the used model is quite a good fit respectively.

The $\operatorname{Exp}(B)$ value in Appendix 1 indicates the increase or decrease in predicted probabilities if the corresponding predictor is increased by one unit. If the value of $\operatorname{Exp}(\mathrm{B})$ exceeds 1 then the predicted probability of occurrence increases, conversely ifExp(B) value is less than 1 , any increase in the corresponding predictor leads to thedecrease of the predicted probability (O'Connell 2005). For example, the Exp (B) value associated with DEBT in the 2011. Hence, when DEBT is raised by one unit the predicted probability of occurrence is 4.2393 times large.

\section{Factor Affecting IS Practices}

Income smoothing behavior was hypothesized to be associated with several factors. As presented previously, the three (3) alternate hypotheses correspond to the variables such of:company size, profitability and total debt. Those variables were treated as independent variables in the logistic regression model and each of these hypotheses will be discussed in the following subsections.

\section{Firm Size and IS Practices}

As shown in $\mathrm{H}_{2}$, this study hypothesized that there is a significant relationship between the IS practices and the company size. Previous studies found that the company size had an ef- fect on income smoothing behavior (Atik 2009; Mansor and Achmad 2009; Nuryanah et al. 2011; Mohammad and Ehsan 2011). In this study, the firm size is measured by total assets, after taking logarithm. Logarithm is used for reduce wide-ranging quantities to smaller scopes (O'Connel 2005). Appendix 1 shows that firm size did not significantly affect to IS practices since at $\alpha=0.1, p=0.755$ in 2009 . These findings lead to the following interpretation, if companies entered into the worst financial situation that affected large and small companies; so management faced the same problems that the company performance was down turn. Therefore managers had to maintain their performance with respect to some market expectations, such as the market income expectation, management (agent) selects optimal accounting procedures for maximizing its benefits, this situation had led managers to engage in income smoothing practices. Therefore, this was the reason why firm size had no significant relationship to IS practices.

\section{Profitability and IS Practices}

Presumably, fluctuations in income streams have a more severe impact on low profitability companies; hence, they have a stronger motivation to smooth income figure. Therefore, this study hypothesized that $\mathrm{H}_{3}$ : There is a significant relationship between the IS practices and the profitability of the company. Appendix 1 shows the effect of profitability factor to income smoothing and there is significant relationship in all five periods. This study concludes that the incidence of IS practices is greater in a less profitable company. Research by Nuryanah et al. (2011) indicate that, when the company is in a good condition with high profit, managers will report the profit as it is to gain the positive impression from the stockholders. In turn, the financial crisis caused listed companies to experience financial insolvency and therefore the income smoothing practice was highly considered by managers if the company were in a less profitable or in a loss position in order to reduce the significant decrease of profit or to reduce the amount of losses. Another explanation is that the manager's motivation to manage income comes from the management's responsibility to achieve targeted profit. Ironically, it often happens that 
the companies themselves who create this pressure to meet the profit target and the market's expectations. Consequently, their managements have incentives to manage earnings to achieve a smooth and growing earnings stream in order to achieve targeted.

\section{Debt Financing and IS Practices}

As seen in $\mathrm{H} 4$, this study hypothesized that there is a significant relationship between the IS practices and the total debt of the company. The previous literature suggests that leveraged firms engage in IS practices to avoid debt covenant defaults, and firm managers that have defaulted on debt contracts may choose to manage company income to avoid heavy costs resulting from covenant violation. Appendix 1 shows a significant relation $(\alpha=0.05)$ between IS practices and debt financing for five years. This finding imply that in the current global economy, companies that have high leverage may be at risk of bankruptcy if they are unable to make payments on their external debt financing and they may also be unable to find new lenders in the future. If a company wishes to take out a new loan, lenders will scrutinize several measures of whether the company is borrowing too much and will demand that it keeps its debt within reasonable boundaries, because that high debt reliance encourages managers to overcome debt covenant through IS practices (Charfeddine and Bouaine 2012; Tseng and Lai 2007).

\section{CONCLUSION, LIMITATION AND SUGGESTIONS}

The research objective is to investigate the use of non-recurring item transactions as smoothing instrument for smoothing company income. The findings show that the highest percentage of using non-recurring item transactions make non-recurring item transactions make $(64 \%)$ in 2009 , and the lowest of nonrecurring item transactions (35\%) in 2013. These findings also assert that Indonesian listed firms tend to use non-recurring item transactions make non-recurring item transactions make as income smoothing instrument to smooth their income. The two independent variables such as profitability and debt financing have significant influence to IS practices.
The limitation this paper that only focused on publicly listed companies in Indonesia, as an emerging capital market. Therefore, the findings reported in this paper might not be generalizable to other firms in other countries with different economic and business settings. The suggestions for future research that future research can develop and combine a better IS practice model. It can develop a particular model for each industry, maybe with different industry characteristics, such as the influence of some other IS instruments to company income that might produce different and new IS models.

\section{REFERENCES}

Abdullah, S.N., K. N. I. K. Ismail., and N. Lode. 2002. Disclosure of extraordinary items and income smoothing behavior in Malaysia. Jurnal Pengurusan 21: 57-75.

Albrecht, W.D., and F.M. Richardson. 1990. Income smoothing by economic sector. Journal of Business Finance and Accounting 17 (5): 713-731.

Ashari, N., H.C. Koh., S. L. Tan., and W. H. Wong. 1994. Factors affecting income smoothing among listed companies in Singapore. Accounting and Business Research 24 (96): 291- 301.

Atik, A. 2009. Detecting income smoothing behaviors of Turkish Listed Companies through empirical tests using discretionary accounting changes. Critical Perspectives on Accounting 20: 591613.

Beattie, V., S. Brown., D. Ewers., B. John., S. Manson., D. Thomas., and M. Turner. 1994. Extraordinary items and income smoothing: A positive accounting approach. Journal of Business Finance and Accounting 21 (6): 791-811.

Black, E. L., T. A. Carnes., and V. J. Richardson. 2000. The value relevance of multiple occurrences of nonrecurring items. Review of Quantitative Finance and Accounting 15 (4): 391- 411.

Cameron, A. B., and L. Stephens. 1991. The treatment of non-recurring item in the income statement and their consistency 
with FASB Concept Statements. $A B$ ACUS 27 (2): 81- 96.

Charfeddine, L., and W. Bouaine. 2012. Income smoothing and CEO job security. Information Management \& Business Review 4 (3): 95- 106.

Chong, G. 2008. Is the income smoothing ethical? The Journal of Corporate Accounting and Finance Nov/Dec: 41- 44.

Eckel, N. 1981. The income smoothing hypothesis revisited. Abacus 17 (1): 28-40.

Elliot, A., and W. Woodward. 2007. Statistical analysis quick reference guidebook. Thousand Oaks: Sage.

Gu, Z., and T. Chen. 2004. Analysts' treatment of nonrecurring items in street earnings. Journal of Accounting and Economics 38 (1-3): 129 -145.

Habib, A. 2005. Firm specific determinants of income smoothing in Bangladesh: An empirical evaluation. Advances in International Accounting 18: 53-71.

Heflin, F., S.S. Kwon., and J. J. Wild. 2002. Accounting choice: Variation in managerial opportunism. Journal of Business Finance and Accounting 29 (7): 1028- 1078.

Mansor, N., and C. A. Achmad. 2009. Board independence, ownership structure, audit quality and income smoothing activities: A study on Malaysian market. Journal of Modern Accounting and Auditing 5 (11): 1-13.

McClave, J.T., P.G. Benson., and T. Sincich 2011. Statistic for Business and Economics. Boston MA: Pearson Education Publication.

Mohammad, N., and K. Ehsan. 2011. An investigation of the income smoothing behavior of growth and value firms (Case study: Teheran stock exchange market). International Business Research 4 (4): 84-93.

Moses, O. D. 1987. Income smoothing and incentives: Empirical test using accounting changes. Accounting Review 62 (2): 358-377.

Nuryanah, S., M. Sardar., and N. Islam. 2011. Corporate governance and perfomance: Evidence from an emerging market. Malaysian Accounting Review 10 (1): $17-42$.

O'Connell, A. A. 2005. Logistic regression models for ordinal response variables. Thousand Oaks, CA: Sage Publications.

Rezvan, H., A. Zinat., S. Mehdi., E. Fahime. 2011. The impact of earnings quality and income smoothing on the perfomance of companies listed in Tehran Stock Exchange. International Journal of Business and Social Science 2 (17): 193-198.

Stefanescu, M. 2009. The effect of SFAS 144 on managers' income smoothing behavior. Diakses pada 21 Desember 2012, dari

htp://dhanna.cox.smu.edu/SMUWeb/ workshop/W20052006

Stolowy, H., and G. Bartov. 2004. Accounts manipulation: A literature review and proposed conceptual framework. Review Accounting and Finance 3 (1): 162.

Tseng, L. J., and C.W. Lai. 2007. The relationship between income smoothing and company profitability: An empirical study. International Journal of Management 24 (4): 727- 823. 


\section{Appendix 1}

Logistic Regression Analysis Output

\begin{tabular}{|c|c|c|c|c|c|c|c|c|c|c|c|c|c|c|c|c|c|c|}
\hline & \multicolumn{5}{|c|}{2009} & \multicolumn{8}{|c|}{2010} & \multicolumn{5}{|c|}{2011} \\
\hline Variables & B & S.E. & Wald & df. & Sig. & $\operatorname{Exp}(B)$ & B & S.E. & Wald & df. & Sig. & $\operatorname{Exp}(B)$ & B & S.E. & Wald & df. & Sig. & $\operatorname{Exp}(B)$ \\
\hline Company Size (SIZE) & -1.324 & 0.550 & 3.097 & 1 & 0.755 & 0.2656 & -1.088 & 0.561 & 2.097 & 1 & 0.205 & 0.2866 & -1.902 & 0.161 & 3.201 & 1 & 0.405 & 0.2039 \\
\hline Debt Financing (DEBT) & 11.420 & 0.707 & 5.850 & 1 & $0.026 * *$ & 8.093 & 12.823 & 0.997 & 2.850 & 1 & $0.029 * *$ & 6.093 & 11.204 & 0127 & 5.810 & 1 & $0.019^{* *}$ & 4.2393 \\
\hline Profitability (PRT) & -11.095 & 0.296 & 4.613 & 1 & $0.014 * *$ & 0.068 & -9.033 & 0.126 & 4.613 & 1 & $0.024 * *$ & 0.968 & -9.801 & 0.809 & 4.013 & 1 & $0.044 * *$ & 3.2968 \\
\hline -2 Log -likelihood Value & & & & & & 46.106 & & & & & & 67.003 & & & & & & 59.966 \\
\hline $\begin{array}{l}\text { Omnibus Test } \\
\text { (Model Chi square) }\end{array}$ & & & & 24.32 & $25(\mathrm{df}=3)(1$ & $p>0.000)$ & & & & & $520(\mathrm{df}=3)$ & $>0.000)$ & & & & 23.3 & $(\mathrm{df}=3)(1$ & $p>0.000)$ \\
\hline $\begin{array}{l}\text { Hosmer and Lemeshow } \\
\text { (Goodness of fit test) }\end{array}$ & & & & 5.5 & $07(\mathrm{df}=3)$ & $p>0.656)$ & & & & & $27(\mathrm{df}=3)$ & $>0.306)$ & & & & & $01(\mathrm{df}=3)($ & $p>0.750)$ \\
\hline Cox and Snell R Square & & & & & & 0.599 & & & & & & 0.669 & & & & & & 0.502 \\
\hline Nagelkerke R Square & & & & & & 0.753 & & & & & & 0.802 & & & & & & 0.702 \\
\hline
\end{tabular}

Table 5: Logistic Regression Analysis Output

\begin{tabular}{|c|c|c|c|c|c|c|c|c|c|c|c|c|}
\hline & \multicolumn{6}{|c|}{2012} & \multicolumn{6}{|c|}{2013} \\
\hline Variables & B & S.E. & Wald & df. & Sig. & $\operatorname{Exp}(B)$ & B & S.E. & Wald & df. & Sig. & $\operatorname{Exp}(B)$ \\
\hline Company Size (SIZE) & -1.144 & 0.661 & 2.102 & 1 & 0.355 & 0.8066 & -2.123 & 0.160 & 3.327 & 1 & 0.305 & 0.2676 \\
\hline Debt Financing (DEBT) & 10.903 & 0.897 & 4.202 & 1 & $0.059 *$ & 6.0193 & 12.003 & 0.067 & 5.503 & 1 & $0.063^{*}$ & 8.2093 \\
\hline Profitability (PRT) & -12.093 & 0.726 & 6.835 & 1 & $0.084 *$ & 0.9168 & -9.733 & 0.029 & 4.013 & 1 & $0.054 *$ & 0.2608 \\
\hline$-2 \log$-likelihood Value & & & & & & 56.126 & & & & & & 50.006 \\
\hline $\begin{array}{l}\text { Omnibus Test } \\
\text { (Model Chi square) }\end{array}$ & & & & 22.2 & $05(\mathrm{df}=3)$ & $>0.000)$ & & & & 33.02 & $0(\mathrm{df}=3)$ & $p>0.000)$ \\
\hline $\begin{array}{l}\text { Hosmer and Lemeshow } \\
\text { (Goodness of fit test) }\end{array}$ & & & & & $20(\mathrm{df}=3)$ & $>0.436)$ & & & & 8.0 & $17(\mathrm{df}=3)$ & $p>0.430)$ \\
\hline Cox and Snell R Square & & & & & & 0.661 & & & & & & 0.769 \\
\hline Nagelkerke R Square & & & & & & 0.817 & & & & & & 0.842 \\
\hline
\end{tabular}

